\title{
In vitro antifungal activities of fungicides based of plants essentials oils (NECO, ASTOUN and FERCA) and phosphorous acid on Phytophthora katsurae (Pythiaceae), causal agent of the premature nut fall and the heart rot of the coconut tree, in Côte d'Ivoire
}

\author{
Koua Serge Beranger N'GORAN ${ }^{*}$, Brahima CAMARA², Aya Carine N'GUESSAN ${ }^{3}$, \\ Nahawa KONE ${ }^{2}$, Marie-Solange TIEBRE ${ }^{1}$, Djakalia OUATTARA ${ }^{1}$ and Severin AKE $^{2}$ \\ ${ }^{1}$ Laboratory of Systematics Herbarium and Botanical Museum, National Center Flora, Félix HOUPHOUËT- \\ BOIGNY University, 22 BP 582 Abidjan 22, Côte d'Ivoire. \\ ${ }^{2}$ Laboratory of Biotechnology, Agriculture and Valorization of Biological Resources, Biosciences Training \\ and Research Unit, Félix HOUPHOUËT-BOIGNY University, 22 BP 582 Abidjan 22, Côte d'Ivoire. \\ ${ }^{3}$ Department of Plant Biology, Biological Sciences Training and Research Unit, Péléforo Gon Coulibaly \\ University, BP 1328 Korhogo, Côte d'Ivoire. \\ *Corresponding author; E-mail: kouaberanger@yahoo.fr; Tel. (+225) 0758415317/0505134701
}

Received: 29-06-2021 $\quad$ Accepted: 20-10-2021 $\quad$ Published: 30-10-2021

\begin{abstract}
The present study aimed at evaluating the antifungal activities of NECO, ASTOUN and FERCA fungicides based of plants essentials oils against Phytophthora katsurae a major constraint in coconut plantations in Côte d'Ivoire. In vitro, the inhibition properties of these fungicides was evaluated at different concentrations $50,100,250,500,1000,1500,2000$ and $2500 \mathrm{ppm}$ and compared to a synthetic fungicide (phosphorous acid) at $1,5,10,25,50,100$ and $150 \mathrm{ppm}$ on the radial growth of the mycelium of an isolated pathogen from a diseased nut. The mycelial growth was measured every day during 10 days in the Petri dishes. The results showed inhibition rates ranging from $1.48 \%$ to $100 \%$. The biopesticides NECO and ASTOUN were effective against Phytophthora katsurae at respectively 149.14 and 272.38 ppm compared to phosphorous acid. NECO was fungitoxic at $2500 \mathrm{ppm}$ and fungistatic at 1500 and $2000 \mathrm{ppm}$. Phosphorous acid was simply fungicidal at 150 ppm. Based on these results, these fungicides based of plants essentials oils could be used as biological control of Pnhytophthora katsurae in coconut plantations in Côte d'Ivoire.
\end{abstract}

(C) 2021 International Formulae Group. All rights reserved.

Keywords: Phytophthora katsurae, coconut plantations, fungicides based of essentials oils, biological control, Côte d'Ivoire.

\section{INTRODUCTION}

Species like Phytophthora, are Oomycete pathogens, which cause significant damage to plants throughout the world (Wong, 2006). They have traditionaly been placed under family Pythiaceae in the Kingdom Chromista, but now current knowledge suggest them closely related to heterokont algae attached to the monophyletic Kingdom Stramenopila (Restrepo et al., 2016). 
In Côte d'Ivoire, Phytophthora species encountered are mainly in cocoa and walnuts production (Allou and de Franqueville, 2001; Coulibaly et al., 2013). Thus, in cocoa production, Phytophthora palmivora and Phytophthora magakarya cause field losses respectively from 10 to $15 \%$ and 40 to $60 \%$ (Pokou et al., 2008). In walnuts production, Phytophthora katsurae causes the tree's premature nuts fall and the meristem dieback called heart rot. These diseases quickly lead to the death of the tree and to crop losses up 1 to $35 \%$ on station (Allou et al., 2003). To fight against this parasitic constraint, several means of control have been recommended, particularly prophylactic, genetic and chemicl control with synthetic products (Allou and de Franqueville, 2001; Mpika et al., 2009b; N'Goran et al., 2010; N'Goran et al., 2020). However, these different methods have many limitations. Thus, chemical control with synthetic products has some disadvantages, particularly the high cost of treatments, the resistance of pathogens to certain molecules (Akantetou et al., 2020).

Facing this situation, the search for other means of control (Ahouansou et al., 2019) that are both effective and respectful to the standards on the local Ivorian market is necessary. To this end, several research works using natural substances such as extracts from local plants have made it possible to fight effectively against several types of plant pests (Kassi et al., 2014 ; Yala et al., 2016; Camara et al., 2017 ; Fofana et al., 2020; Nyaka et al., 2021). This has led to the formulation of many biopesticides (Camara et al., 2007; Camara et al., 2010; Yala et al., 2017; Akantetou et al., 2020).

This study aimed at proposing a means of biological control through the use of plant extracts against Phytophthora katsurae in order to maintain the production of coconut plantations.

\section{MATERIALS AND METHODS Materials}

The fungal material used was an isolate of Phytophthora katsurae isolated from a diseased nut collected at the Marc Delorme coconut station of the National Agronomic
Research Center (CNRA) located at Port-Bouët in the Autonomous District of Abidjan, in Ivory Coast. The biofungicides were formulations based on essential oils from hydrodistillation of leaves and coded NECO, ASTOUN and FERCA. As for the synthetic fungicide, it consisted of phosphorous acid used as a positive control.

\section{Methods}

\section{Culture and conservation of Phytophthora katsurae strains}

Both modified V8 and Ribeiro media were used. Modified V8 medium was used for refreshing and preservation of Phytophthora katsurae strain. Modified Ribeiro medium was used for in vitro evaluation of the antifungal potential of biopesticides and phosphorous acid. One liter of modified V8 medium is composed of $45 \mathrm{ml}$ of $\mathrm{V} 8$ vegetable juice, $21 \mathrm{~g}$ of Agar-agar and $955 \mathrm{ml}$ of distilled water (N'goran, 2010). After autoclave sterilization at 1.5 bars at $121{ }^{\circ} \mathrm{C}$ for $30 \mathrm{~min}$, the resulting solution after slight cooling was dispensed into $90 \mathrm{~mm}$ diameter Petri dishes under a laminar flow hood in the presence of flame. Using a cookie cutter, $6 \mathrm{~mm}$ diameter mycelial discs were taken from Petri dishes containing Phytophthora katsurae cultures and transplanted into the center of Petri dishes containing V8-agar medium. As for the modified Ribeiro medium, it has a composition containing $4.5 \mathrm{~g}$ of glucose, $0.1 \mathrm{~g}$ of $\mathrm{L}$ asparagine, $0.15 \mathrm{~g}$ of potassium nitrate $\left(\mathrm{KNO}_{3}\right), 1.36 \mathrm{~g}$ of potassium dihydrogen phosphate $\left(\mathrm{KH}_{2} \mathrm{PO}_{4}\right), 0.5 \mathrm{~g}$ of Magnesium sulfate $\left(\mathrm{MgSO}_{4}, 7 \mathrm{H}_{2} \mathrm{O}\right)$ and calcium chloride $\left(\mathrm{CaCl}_{2}\right)$ as base solution A, a Microelement solution of $41.1 \mathrm{mg}$ Sodium Molybdate $\left(\mathrm{Na}_{2} \mathrm{MoO}_{4}, \mathrm{H}_{2} \mathrm{O}\right), \quad 87.8 \mathrm{mg}$ Zinc Sulfate $\left(\mathrm{ZnSO}_{4}, 7 \mathrm{H}_{2} \mathrm{O}\right), 7.85 \mathrm{mg}$ Copper Sulfate $\left(\mathrm{CuSO}_{4}, \mathrm{H}_{2} \mathrm{O}\right), 15.4 \mathrm{mg}$ Manganese Sulfate II $\left(\mathrm{MnSO}_{4}, \mathrm{H}_{2} \mathrm{O}\right), 0.5 \mathrm{mg}$ Sodium Tetraborate $\left(\mathrm{Na}_{2} \mathrm{~B}_{4} \mathrm{O}_{7}\right), 1000 \mathrm{ml}$ distilled water as solution $\mathrm{B}$ and then a ferric solution of $50 \mathrm{mg}$ Iron III chloride, $2.6 \mathrm{mg}$ EDTA, $1.5 \mathrm{mg} \mathrm{KOH}$ as solution $\mathrm{C}$ to which $17 \mathrm{~g}$ Agar-Agar is added to obtain the solid medium. The $\mathrm{pH}$ of the medium was adjusted to 6.2 with $6 \mathrm{M} \mathrm{KOH}$ using a $\mathrm{pH}$ meter before autoclaving at $1.5 \mathrm{bar}$ for $30 \mathrm{~min}$. After autoclaving, $1 \mathrm{ml}$ of sterilized 
Thiamine solution was added to the medium while cooling to approximately $50{ }^{\circ} \mathrm{C}$ before being dispensed into the Petri dishes (King, 2007).

\section{Preparation of the test media}

The $100 \mathrm{ml}$ Ribeiro media were prepared by autoclaving at a temperature of $121{ }^{\circ} \mathrm{C}$ under a pressure of 1 bar for $30 \mathrm{~min}$. After cooling the media at room temperature to the supercooling temperature, the fungicides were added to the media to obtain the concentrations of $1 ; 5 ; 10 ; 25 ; 50 ; 100$ and 150 ppm for the phosphorous acid fungicide and 50; 100; 250; 500; 1000, 1500; 2000 and 2500 ppm for the NECO, ASTOUN and FERCA biological fungicides. Ribeiro media amended with the different fungicides were homogenized and distributed in a laminar flow hood in $90 \mathrm{~mm}$ diameter Petri dishes at a rate of $18 \mathrm{ml}$ per dish. The controls were dishes containing no fungicide. For each fungicide, five Petri dishes were used per concentration.

\section{Seeding and incubation}

Using a cookie cutter, $6 \mathrm{~mm}$ diameter mycelial discs were taken from 7 day old cultures and seeded in the center of fungicidetreated and non-fungicide-treated Petri dishes. The cultures were sealed with the stretch film and incubated at $25^{\circ} \mathrm{C}$ for 10 days.

\section{Assessment of mycelial growth}

Radial growth was measured every day in millimeter, excluding the plug until 10 days. Measurements of mycelial radial growth were made along two perpendicular lines drawn on the reverse side of each Petri dish that intersected at a point in the middle of the mycelial ring. The effect of fungicides on mycelial growth of the fungus was determined through the rate of mycelial growth inhibition calculated by the formula of Hmouni et al. (1996):

$I(\%)=\frac{D o-D c}{D o}$

( $\mathrm{I}=$ inhibition rate; Do $=$ average diameter of mycelial growth of colonies in control boxes; $\mathrm{Dc}=$ average diameter of mycelial growth of colonies at concentration (c) of synthetic fungicide or biological fungicides).

From the ed50v10 (1) software, the mycelial growth inhibition rates are transformed into probit values with the regression lines in the form of $y=a \log x+b$ according to the transformed formula of Paranagama et al. (2003) ( $Y$ the probit, a the regression coefficient, $\mathrm{b}$ the constant, $\mathrm{x}$ the fungicide concentration, $\log$ the decimal $\log$ arithm). The equations of these regression lines allowed us to determine the $\mathrm{IC}_{50}$ and $\mathrm{IC}_{90}$, which are the fungicide concentrations that reduce the mycelial growth of the fungus by half 50\% and by $90 \%$ (Oxenham et al., 2005; Neri et al., 2006).

\section{Test of fungitoxicity of fungicides}

When no mycelial growth has been observed for a given concentration of fungicide, then the mycelial disc is transplanted into a new Petri dish containing Ribeiro culture medium without addition of fungicide. All these plates are kept under the same conditions. If there is no mycelial regrowth the concentration is said to be fungicidal and if not it is said to be fungistatic (Soro et al., 2010).

\section{Statistical analysis}

All data obtained were entered into Excel, calculated and analysed with Statistica 7.1. The calculation of the inhibition rates allowed to evaluate the occupation of the mycelial growth of the strains on the culture media. An Analysis of Variance with a classification criterion was used to study the sensitivity of the Phytophthora katsurae strain to the different fungicides used. The NewmanKeuls test with a $5 \%$ probability allowed to classify the proportions obtained.

\section{RESULTS}

Effect of different concentrations of the synthetic fungicide phosphorous acid on the mycelial growth of Phytophthora katsurae

On day 1 , a $100 \%$ inhibition rate was observed with the 50, 100 and $150 \mathrm{ppm}$ concentrations. For $150 \mathrm{ppm}$, this inhibition rate remained constant until day 10 . For the 100 ppm concentrations, a slight decrease in the inhibition rate was observed from the 9th day up to $98.22 \%$ on the 10th day, on the other hand with the $50 \mathrm{ppm}$ concentration from the 3rd day a progressive decrease in the inhibition rate was observed reaching $76.72 \%$ on the 10 th day. With the concentrations $1 ; 5 ; 10$ and $25 \mathrm{ppm}$, on the first day the inhibition rates are lower than $80 \%$. At the concentration of $1 \mathrm{ppm}$ the 
phosphorous acid had no effect on the mycelial growth, from the first day, a practically null inhibition rate until the 10th day was observed. For concentrations of 5, 10 and $25 \mathrm{ppm}$ the inhibition rates decreased progressively with time. The inhibition rates recorded at day 10 for these are respectively $5.48 \% ; 1.48 \%$; and $10 \%$ (Figure 1).

Effect of different concentrations of the biological NECO fungicide on the mycelial growth of Phytophthora katsurae

For NECO biological fungicide, concentrations 1500, 2000 and 2500 ppm showed complete inhibition of mycelial growth from day 1 to day 10 . For the concentrations 50; 100; 250; 500 and 1000 ppm the inhibition rates progressively decreased with time. For the latter, on the last day, the inhibition rates were respectively $36.39 \%$; $39.57 \%$; $52.67 \%$; $53.33 \%$ and $62.86 \%$ (Figure 2).

Effect of different concentrations of the biological ASTOUN fungicide on the mycelial growth of Phytophthora katsurae

For ASTOUN biological fungicide, the daily mycelial growths of Phytophthora katsurae observed decreased progressively with time. However, at $2500 \mathrm{ppm}$ this rate was $89.11 \%$ on the last day and was higher compared to the concentrations $50 ; 100 ; 250$; 500; 1000; 1500 and 2000 ppm whose inhibition rates were respectively 5.74\%; $35.24 \%$; 39.06\%; 43.81\%; 54.29\%; 61.54\% and $65.22 \%$ (Figure 3 ).

Effect of different concentrations of the biological FERCA fungicide on the mycelial growth of Phytophthora katsurae

With FERCA biological fungicide, all concentrations resulted in a progressive decrease of the inhibition rate. Thus, the highest inhibition rates were recorded with the concentrations of 2000 and 2500 ppm, with $54.07 \%$ and $80.41 \%$ respectively. For the concentrations of 50;100;250; 500; 1000 and $1500 \mathrm{ppm}$, the inhibition rates recorded were $7.17 ; 8.87 ; 14.12 ; 16.79 ; 22.49$ and $15 \%$ (Figure 4).
Comparative effects of natural fungicides and synthetic fungicide on in vitro mycelial growth of Phytophthora katsurae

The different fungicides used acted differently on the mycelial growth of Phytophthora katsurae. A highly significant difference $\quad(\mathrm{F}=1095.677 ; \quad \mathrm{P}=0.000) \quad$ was observed between the fungicides for all concentrations used. Thus, NECO biological fungicide recorded the best inhibition rate with a value of $74.56 \%$ followed by ASTOUN and phosphorous acid fungicides with respective inhibition rates of $66.80 \%$ and $56.06 \%$. The biological fungicide FERCA with an inhibition rate of about $48.55 \%$ was the one that gave the lowest inhibition rate (Figure 5).

50 and $90 \%$ inhibitory concentrations (IC 50 and $\mathrm{IC}_{90}$ ) of mycelial growth of Phytophthora katsurae

The 50 and $90 \%$ inhibitory concentrations of mycelial growth of Phytophthora katsurae differed according to the fungicides. Among the organic fungicides, NECO recorded the lowest concentration (149.14 ppm) that inhibits 50\% of the mycelial growth of the pathogen. This concentration is very low compared to the $\mathrm{IC}_{50}$ of the synthetic fungicide which is $810.32 \mathrm{ppm}$. The highest $\mathrm{IC}_{50}$ of $1016.39 \mathrm{ppm}$ was obtained with FERCA. The $\mathrm{IC}_{90}$ was $1662.9 ; 1793.12$ and $2269.28 \mathrm{ppm}$ respectively for, NECO, ASTOUN and FERCA (Table 1).

\section{Test of fungitoxicity of fungicides}

Among the biological fungicides no mycelial growth was observed for the concentrations of $1500 ; 2000$ and $2500 \mathrm{ppm}$ of NECO. For phosphorous acid at the concentration of $150 \mathrm{ppm}$ there was no mycelial growth. When the explants from these concentrations were transplanted on Ribeiro medium without fungicide, there was no mycelial growth for the explant from the 2500 ppm NECO concentration, contrary to the 150 ppm phosphorous acid concentration where the fungus resumed its growth. The NECO fungicide is therefore fungitoxic at $2500 \mathrm{ppm}$ and fungistatic at 1500 and $2000 \mathrm{ppm}$, whereas the phosphorous acid is simply fungicidal at 150 ppm (Table 2). 


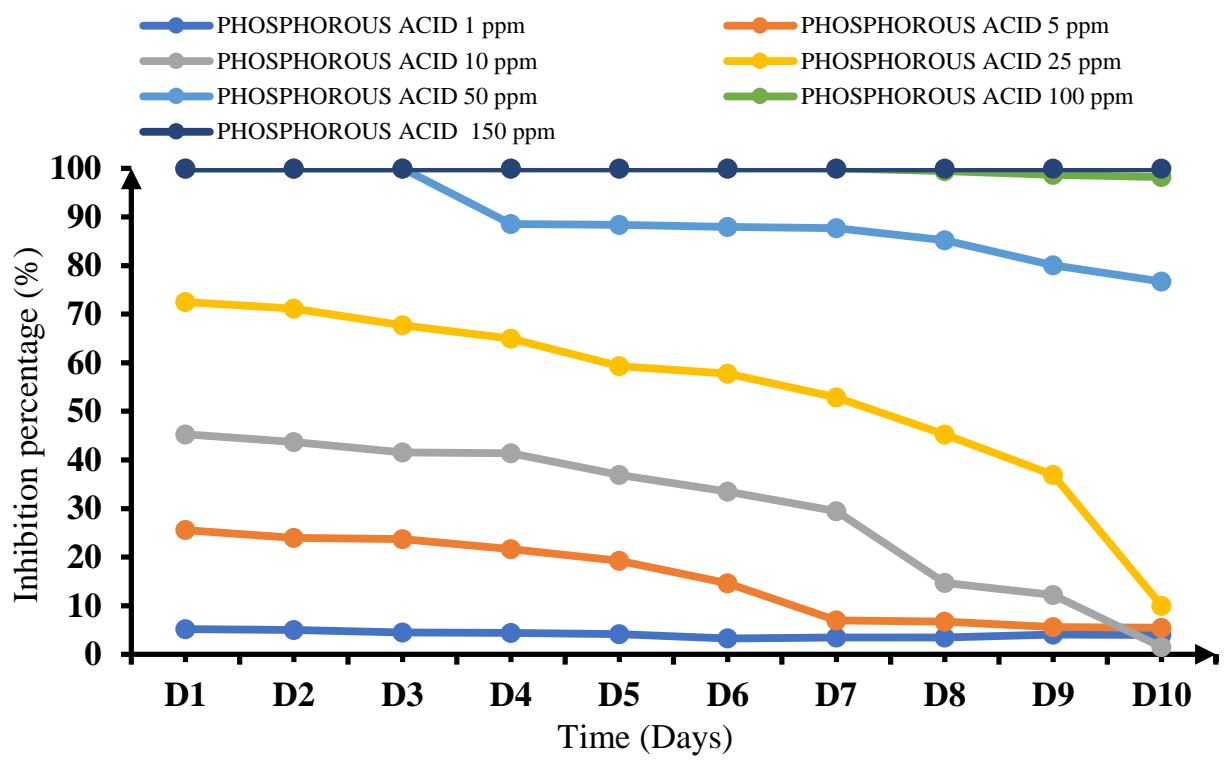

Figure 1: Variation in the daily mycelial growth inhibition rate of Phytophthora katsurae according to different phosphorous acid concentrations.



Figure 2: Variation in the daily mycelial growth inhibition rate of Phytophthora katsurae according to different concentrations of NECO biological fungicide. 


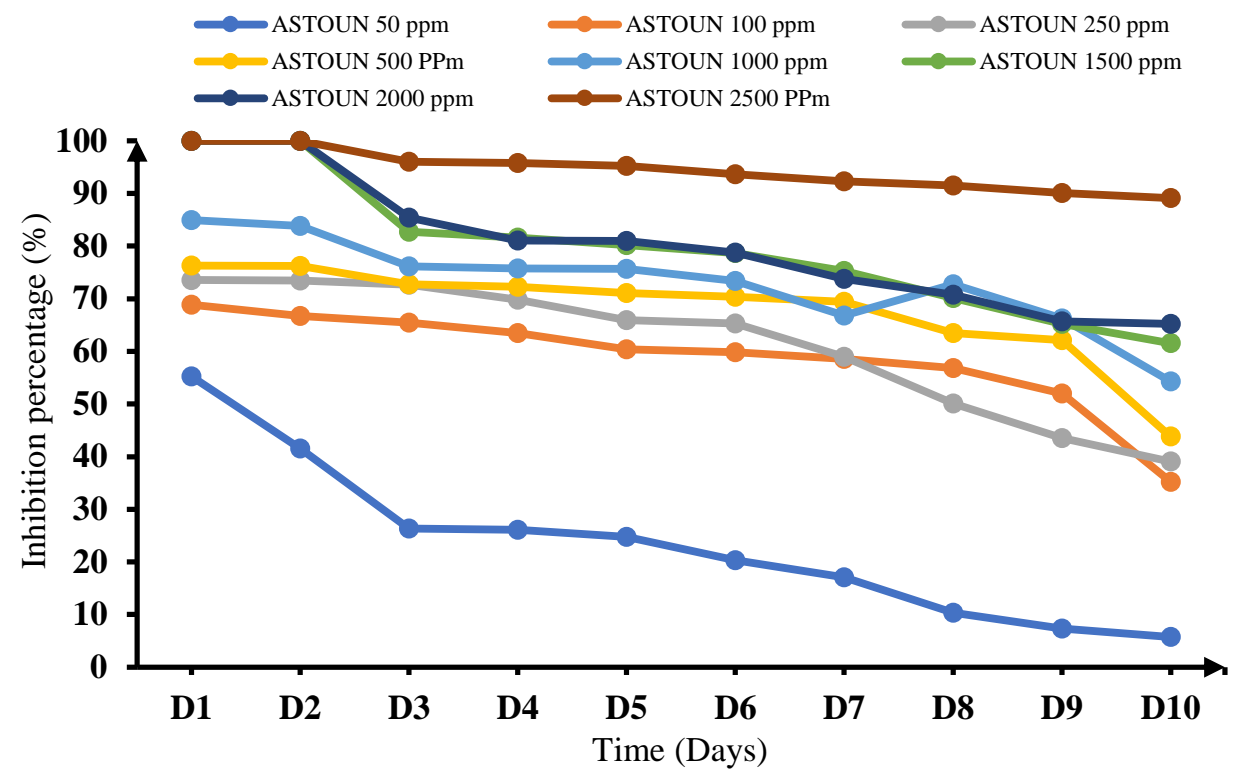

Figure 3: Variation in the daily mycelial growth inhibition rate of Phytophthora katsurae according to different concentrations of ASTOUN biological fungicide.

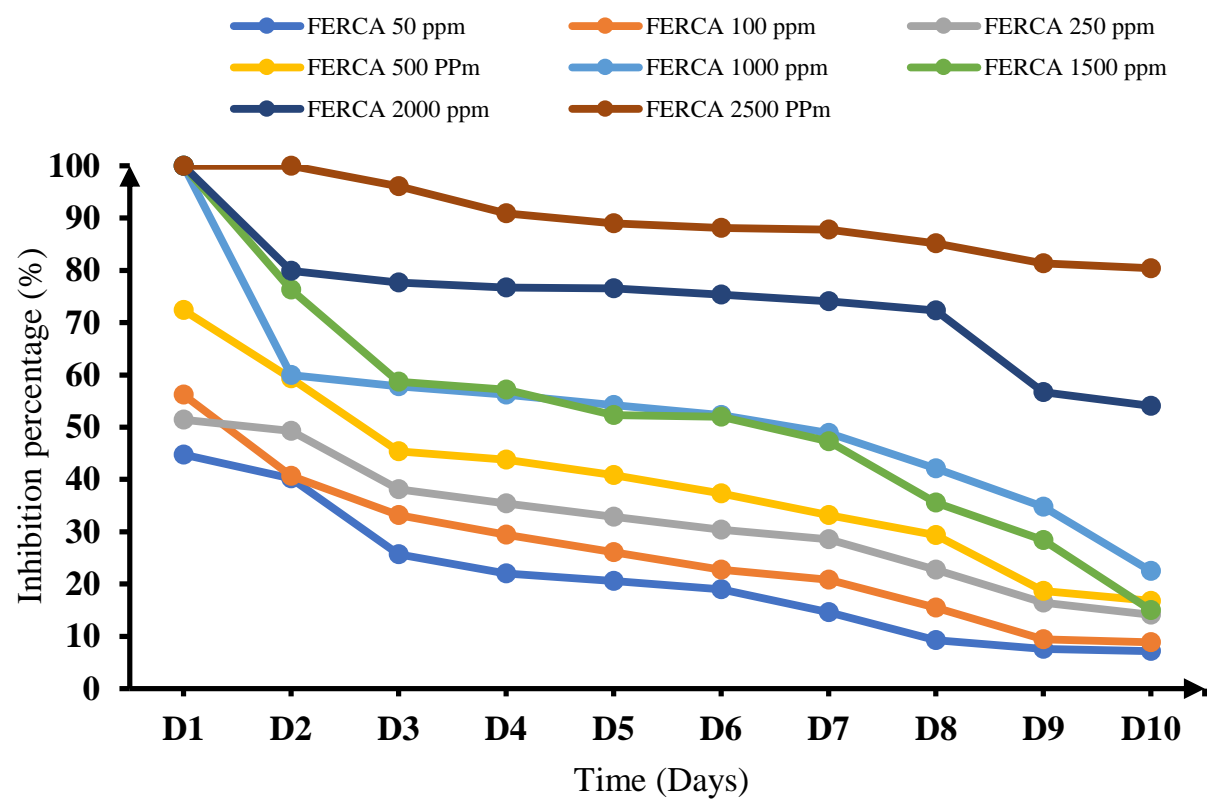

Figure 4: Variations in the daily mycelial growth inhibition rate of Phytophthora katsurae according to different concentrations of FERCA biological fungicide. 


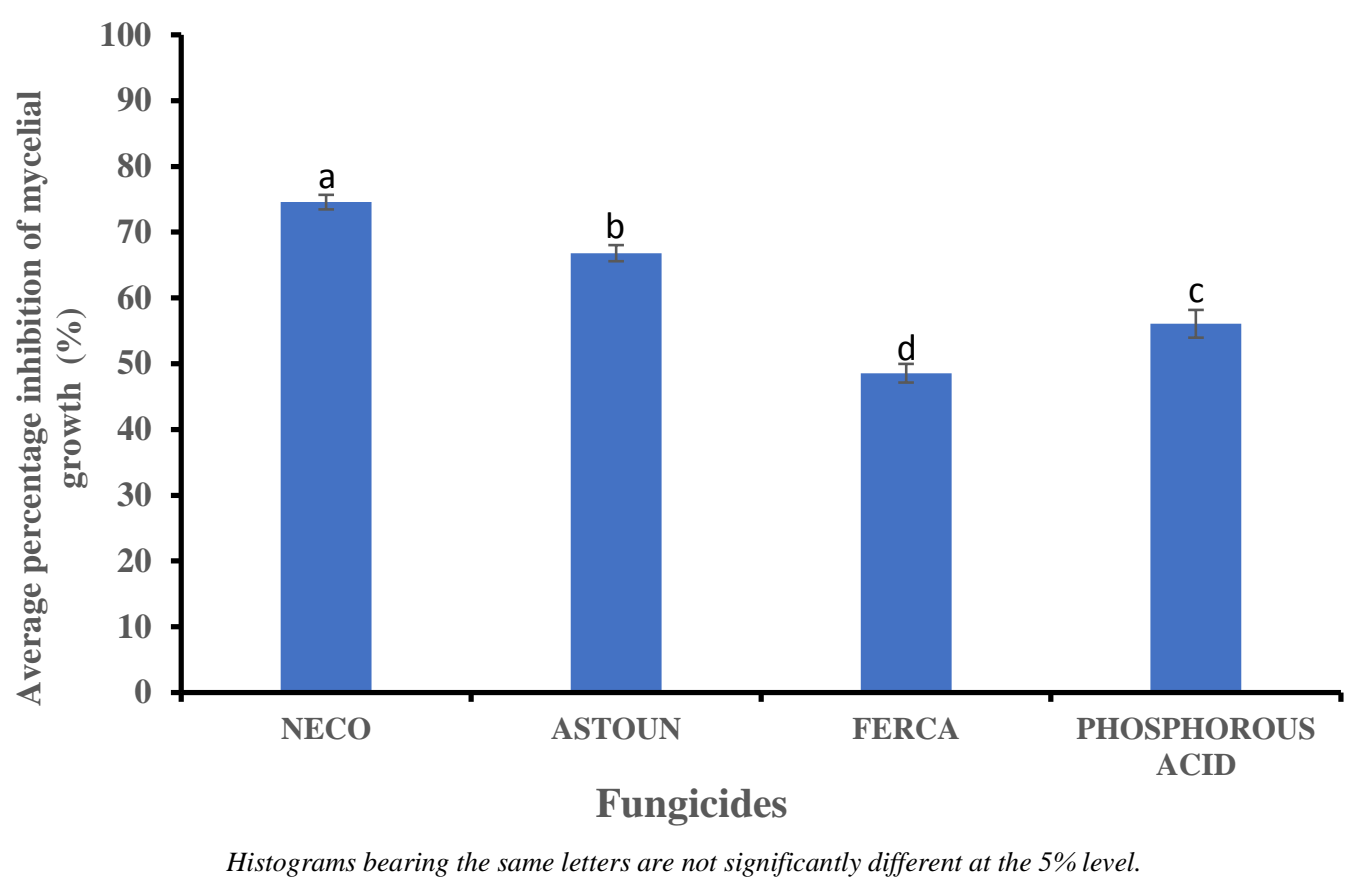

Figure 5: Average inhibition rate of mycelial growth of Phytophthora katsurae according to the biological fungicides NECO, ASTOUN, FERCA and the synthetic fungicide Phosphorous acid.

Table 1: $\mathrm{IC}_{50}$ and $\mathrm{IC}_{90}$ inhibitory concentrations of NECO, ASTOUN, FERCA biological fungicides and the synthetic fungicide Phosphorous acid.

\begin{tabular}{lll}
\hline FUNGICIDES & IC $_{\mathbf{5 0}}(\mathbf{p p m})$ & IC $_{\mathbf{9 0}}(\mathbf{p p m})$ \\
\hline NECO & 149.14 & 1662.9 \\
ASTOUN & 272.38 & 1793.12 \\
FERCA & 1016.38 & 2269.3 \\
PHOSPHOROUS ACID & 810.316 & 1535.6 \\
\hline
\end{tabular}

Table 2: Fungitoxicity of fungicides.

\begin{tabular}{lll}
\hline FUNGICIDES & Concentration (ppm) & Mycelial growth \\
\hline NECO & 1500 & + \\
NECO & 2000 & + \\
NECO & 2500 & - \\
PHOSPHOROUS ACID & 150 & + \\
\hline
\end{tabular}

(+): Resumption of growth; (-): No resumption of growth. 


\section{DISCUSSION}

In this study, the effects of the biopesticides NECO, ASTOUN and FERCA were evaluated and compared to the synthetic fungicide, the phosphorous acid. Thus, the Phosphorous acid significantly reduced the mycelial growth of Phytophthora katsurae from $50 \mathrm{ppm}$. These results are similar to those obtained by N'goran et al. (2010) who showed the effectiveness of the phosphorous acid in the control of phytophthora katsurae.

Like phosphorous acid, the biological fungicides acted significantly on the mycelial growth of Phytophthora katsurae. These results are in agreement with those of Fofana et al. (2020) on the antifungal activity of these three biological fungicides on Phytophthora palmivora responsible for brown rot on the cocoa tree. As these different biological fungicides are essential oil based formulations, the antifungal, antibacterial and insecticidal activity of these essential oils has already been proven during the work of Camara et al. (2007) on Mycosphaerella fijiensis which caused leaf diseases of banana and plantain in West Africa. The effectiveness of these biological fungicides was according to the used concentrations. Indeed, NECO totally inhibited the growth of Phytophthora katsurae from $1500 \mathrm{ppm}$. These results are similar to those obtained by Silue et al. (2018) who showed the efficiency of NECO biological fungicide in inhibiting the mycelial growth of Colletotrichum at concentrations of 300, 400, $500 \mathrm{ppm}$. Also, the work of Yeo (2017) showed that NECO completely reduced the mycelial growth of Sclerotium rolfsii at the concentrations of 3000, 5000, 7000 and 10000 $\mathrm{ppm}$. The antifungal activity of NECO would be due to its chemical composition. NECO is formulated from essential oil whose active components are thymol (Kassi et al., 2014) and eugenol. Thymol and eugenol are responsible for the fungicidal (Chami, 2005) and bactericidal activity of essential oils containing them (Cox et al., 2000). Also, in vitro, Camara et al. (2007), showed that NECO inhibits spore production and mycelial growth of Deightoniella torulosa strains. Concerning the biofungicide ASTOUN, the mycelial growth was reduced by half from $1000 \mathrm{ppm}$. These results are contrary to those of N'Goran (2017) who showed that the ASTOUN biofungicide at $100 \mathrm{ppm}$ inhibited mycelial growth by half. This difference would be due to the degree of sensitivity of the fungus to different concentrations of this biological fungicide. According to Gabriel et al. (2013) and El Amri et al. (2014) the biological activities can be explained first by the chemical composition of these oils, but also, by the quantitative and qualitative variability of its components. The antifungal activity of ASTOUN would be due to its chemical composition. The active components of ASTOUN are thymol and citronellol. The difference in activity between NECO and ASTOUN biological fungicides would then be due to the absence of eugenol in the chemical composition of ASTOUN. FERCA biological fungicide was the least effective, inhibiting mycelial growth of Phytophthora katsurae by half only at the concentration of $2000 \mathrm{ppm}$. Thus, the biopesticides NECO and ASTOUN could be recommended as biological control of Phytophthora katsurae of coconut tree.

\section{Conclusion}

Mycelial growth of Phytophthora katsurae was dependent on the used products and concentrations. Among the biological fungicides used, NECO and ASTOUN showed an efficiency in the control of Phytophthora katsurae at $149.14 \mathrm{ppm}$ and $272.38 \mathrm{ppm}$ respectively compared to the phosphorous acid and synthetic fungicide. The use of these biopesticides could be a solution in the control of immature nut drop and heart rot of coconut tree, especially through the implementation of efficiency tests in plantations.

\section{COMPETING INTERESTS}

The authors declare that they have no competing interests in the publication of this work.

\section{AUTHORS' CONTRIBUTIONS}

KSBN defined the theme and objectives of this study. He guided the methodological approach and the results obtained. $\mathrm{He}$ participated in the analysis of the data and the drafting of the proposed manuscript. BC and 
CAN contributed to the definition of the methodological approach and the obtained results. NK collected the field and laboratory data and participated in the writing of this manuscript. MST, DO and SA corrected the form and content of the proposed manuscript. All authors read and approved this manuscript.

\section{ACKNOWLEDGMENTS}

Authors are grateful to Laboratory of Biotechnology, Agriculture and Valorization of Biological Resources and Dr SILUE Napalo for laboratory activities and facilities.

\section{REFERENCES}

Ahouansou AC, Medegan Fagla SR, Tokoudagba JM, Toukourou H, Badou YK, Gbaguidi FA. 2019. Chemical composition and larvicidal activity of the essential oil of Cymbopogon nardus (L.) Rendle on Anopheles gambiae. International Journal of Biological and Chemical Sciences, 13(3): 1861-1869. DOI: 10.4314/ijbcs.v13i3.53

Akantetou PK, Nadio NA, Bokobana ME, Tozou P, Kilimou P, Koba K, Poutouli W, Raynaud C, Sanda K. 2020. Effet aphicide de l'huile essentielle de Ocimum basilicium L. et de son composé majoritaire sur le puceron du cotonnier Aphis gossypii Glover (Homoptera : Aphididae) au Togo. International Journal of Biological and Chemical Sciences, 14(1): 84-96. DOI: https://dx.doi.org/10.4314/ijbcs.v14i1.8

Allou K, Ballo K, Hala N, Konan JL, Akanvou R. 2003. Tolérance variétale du cocotier à Phytophthora katsurae en Côte d'Ivoire. AFPP- Seventh International Conference on Plant Diseases, Tours, France, 3-4-5 December 2003, 8p.

Allou K, de Franqueville H. 2001. Efficacité comparée du phosetyl-Al et de l'acide phosphoreux dans la lutte contre Phytophthora katsurae du cocotier. Agronomie Africaine, 13(3): 95-139. DOI: 10.4314/aga.v13i3.1602

Camara B, Amari LDGE, Cherif M, Dick E, Tuo S, Kanko C, Kone D. 2017. In vitro inhibitory effect of Monodora myristica and Eucalyptus torelliana essential oils on the mycelial growth of Mycosphaerella fijiensis a pathogenic agent of the black leaf streak disease of banana and plantain. International Journal of Green and Herbal Chemistry, 6(3): 51-61. DOI: https://doi.org/10.24214/ijghc/hc/6/3/516 1

Camara B, Dick E, Sako A, Kone D, Kanko C, Boye MAD, Aké S, Anno A. 2010. Lutte biologique contre Deightoniella torulosa (Syd.) Ellis, un champignon de la phyllosphère des bananiers par l'application des huiles essentielles de Eucalyptus platyphylla F. Muell. et de Melaleuca quinquenervia. L. Phytothérapie, 8(4): 240-244. DOI: https://doi.org/10.1007/s10298-0100568-3

Camara B, Kone D, Kanko C, Anno A, Ake S. 2007. Activité antifongique des huiles essentielles de Ocimum gratissimum L., de Monodora myristica (Gaaertn) dunal et de deux produits de synthèses (impulse et folicur), sur la croissance mycélienne et la production de spore in vitro de Deightoniella torulosa (Syd.) ellis. Revue ivoirienne des Sciences et Technologies, 9(2007): 187- 201.

Chami F. 2005. Evaluation in vitro de l'action antifongique des huiles essentielles d'origan et de girofle et de leurs composés majoritaires in vivo: Application dans la prophylaxie et le traitement de la candidose vaginale sur des modèles de rat et de souris immunodéprimés. Thèse de Doctorat, Université Sidi Mohamed Ben Abdellah, Maroc, 266p.

Coulibaly K, Kebe IB, Koffi NK, Mpika J, Kone D. 2013. Caractérisation des isolats de Phytophthora spp du verger cacaoyers de Côte d'Ivoire. Journal of Applied Biosciences, 70: 5567-5579. DOI: https://dx.doi.org/10.4314/jab.v70i1.987 57

Cox SD, Mann CM, Markham JL, Bell HC, Gustafson JE, Warmington JR, Wyllie SG. 2000. The mode of antimicrobial action of the essential oil of Melaleuca alternifolia (tea tree oil). Journal of Applied Microbiology, 88(1): 170-175. 
DOI: https://doi.org/10.1046/j.13652672.2000.00943.x

El Amri J, Elbadaoui K, Zai T, Bouhab B, Chakir S, Alaoui TI. 2014. Etude de l'activité antibatérienne des huiles essentielles de Teucrium capitatium L. et de l'extrait de Silène vulgaris sur les différentes souches testées. Journal of Applied Biosciences, 82: 7481-7492. DOI: $10.4314 /$ jab.v82i1.16

Fofana B, Soro S, Kassi F, Silué N, Zouzou M, Kone D. 2020. Valorisation de biofongicides d'origine végétale en vue d'une gestion éco-efficiente de la pourriture brune des cabosses du cacaoyer causée par Phytophthora palmivora. Journal of Animal and Plant Sciences, 44(2): 7654-7676. DOI: https://doi.org/10.35759/JAnmPlSci.v442.6

Gabriel I, Alleman F, Dufourcq V, Perrin F, Gabarrou J. 2013. Utilisation des huiles essentielles en alimentation des volailles.2. Hypothèses sur les modes d'action impliqués dans les effets observés. INRAE, Production Animale, 26(1): 13-24. DOI: https://doi.org/10.20870/productionsanimales.2013.26.1.3131

Hmouni A, Hajlaoui M, Mlaiki A. 1996. Résistance de Botrytis cinerea aux benzimidazoles et aux dicarboximides dans les cultures abritées de tomate en Tunisie. OEPP/EPPO Bulletin, 26: 697705.

Kassi FM, Badou OJ, Tonzibo ZF, Salah Z, Amari L, Dadé GE, Koné D. 2014. Action $\mathrm{du}$ fongicide naturel NECO contre la cercosporiose noire (Mycosphaerella fijiensis Morelet) chez le bananier plantain (AAB) en Côte d'Ivoire. Journal of Applied Biosciences, 75: 6183-6191. DOI: https://doi.org/10.4314/jab.v75i1.3

King M. 2007. The phosphate responsive transcriptome of Phytophthora cinnamomi. $\mathrm{PhD}$ Thesis, Murdoch University, Australia, 180p.

Mpika J, Kébé IB, Issali AE, N'guessan FK, Druhinima S, Komon-Zélazowska M, Kubicek CP, Aké S. 2009b. Antagonist potential of Trichoderma indigenous isolates for biological control of Phytophthora palmivora the causative agent of black pod disease on cocoa (Theobroma cacao L.) in Côte d'Ivoire. African Journal of Biotechnology, 8(20): 5280-5293.

DOI: https://doi.org/10.5897/AJB09.393

Neri F, Mari M, Brigati S. 2006. Control of Penicillium expansum by plant volatile compounds. Plant Pathology, 55: 100105. DOI: https://doi.org/10.1111/j.13653059.2005.01312.x

N'goran NS. 2017. Caractérisation des champignons infectant les agrosystèmes de manguiers et effets des biofongicides à base d'huiles essentielles sur Colletotrichum sp. agent responsable de l'anthracnose au nord de la Côte d'Ivoire. Mémoire de Master, Université Félix Houphouët-Boigny, Abidjan, Côte d'Ivoire, 51p.

N'Goran KSB, Kouassi AF, Gogbeu SJ, Ochou GEC, Allou K, Ake S. 2020. In vivo expression and evolution of Phytophthora katsurae (Pythiaceae) symptoms on two coconut varieties EGD and PB $121^{+}$after treatment with phosphorous acid in Southern Côte d'Ivoire. International Journal of Sciences, 9(10): 31-34. DOI: https://doi.org/10.18483/ijsci.2371

N'goran B, Allou K, Yao A, Konan JL, M'pika J, Lekadou T, Issali A, Ake S. 2010. Action de l'acide phosphoreux in vitro sur Phytophthora katsurae (Pythiaceae), parasite du cocotier en Côte d'Ivoire. International Journal of Biological and Chemical Sciences, 4(6): 1976-1987. DOI: 10.4314/ijbcs.v4i6.64948

Nyaka AICN, Fadimatou SNMZ, Dzokouo CUD, Bourou S, Yaouba A. 2021. Effet antifongique de deux extraits de plantes sur les agents pathogènes identifies sur les fruits de l'anacardier (Anacardium occidentale L.) au Nord Cameroun. International Journal of Biological and Chemical Sciences, 15(3): 1121-1139. DOI: $10.4314 /$ ijbcs.v15i3.21

Oxenham SK, Svoboda KPN, Walters DR. 2005. Antifungal activity of essential oil Basil (Ocimum basilicum). Phytopathology, 153: 174 - 180. DOI: 
https://doi.org/10.1111/j.1439-

0434.2005.00952.x

Paranagama PA, Abeysekera KHT, Abeywickrama K, Nugaliyadde L. 2003. Fungicidal and anti-aflatoxigenic effects of the essential oil of Cymbopogon citrates (DC.) Stapt. (lemongrass) against Aspergillus flavus Link. Isolated from stored rice. Letter in Applied Microbiology, 37: 86-90. DOI: https://doi.org/10.1046/j.1472765X.2003.01351.X

Pokou ND, N'goran JAK, Kébé I, Eskes A, Tahi M, Sangaré A. 2008. Levels of resistance to Phytophthora pod rot in cocoa accessions selected on farm in Côte d'Ivoire. Crop protection, 27: 302-309. DOI: 10.1016/j.cropro.2007.07.012

Restrepo S, Enciso J, Tabima J, Riano-Pachon MD. 2016. Evolutionary history of the group formely known as protists using a phylogenomics approach. Revista de la Academia Colombiana de Ciencias Exactas, Fisica y Naturales, 40(154): 147-160.

DOI: http://dx.doi.org/10.18257/raccefyn.277

Silue N, Abo K, Johnson F, Camara B, Kone M, Kone D. 2018. Evaluation in vitro et in vivo de trois fongicides de synthèse et d'un fongicide biologique sur la croissance et la sévérité de Colletotrichum gloeosporioides et de Pestalotia heterornis, champignons responsables de maladies foliaires de l'anacardier (Anacardium occidentale L.) en Côte d'Ivoire. Agronomie Africaine, 30(1): 107 - 122.

Sirima A, Sereme A, Sereme D, Koita K, Nana TA, Sawadogo M. 2020. Effets de quatre huiles essentielles sur la croissance mycélienne radiale d'un isolate de Alternaria sp. au Burkina Faso. International Journal of Biological and
Chemical Sciences, 14(3): 762-771. DOI: https://doi.org/10.4314/ijbcs.v14i3.10

Soro S, Ouattara D, Zirihi G, Kanko C, N'guessan EK, Koné D, Kouadio JY, Aké S. 2010. Effet inhibiteur in vitro et in vivo de l'extrait de poudre et de l'huile essentielle de Xylopia aethiopica (Dunal) A. Rich. (Annonaceae) sur Fusarium oxysporum f. sp Radicis-lycopersici (Forl), champignon parasite des cultures de tomate. European Journal of Scientific Research, 39(2): 279-288.

Wong MH. 2006. Phosphite induces morphological and molecular changes in Phytophthora species. Master of Philosophy, University of Adelaide, Australia, 129p.

Yala JF, Mabika MR, Camara B, Souza A, Lepengue AN, Tuo S, Kone D, M'Batchi B. 2016. In vitro antibacterial activity of Cymbopogon citratus, Eucalyptus citriodora, Lippia multiflora, Melaleuca quinquenervia essential oils and $\mathrm{Neco}{ }^{\circledR}$ on extended-spectrum B-lactamases producing or non-producing bacterial strains. Journal of Medicinal Plants Research, 10(43): 796-804. DOI: https://doi.org/10.5897/JMPR2016.6272

Yala JF, Mabika MR, Camara B, Tuo S, Souza A, Lepengue AN, Koné D, M'batchi B. 2017. Assessment of the antibacterial activity of four essential oils and the biobactericide Neco. International Journal of Phytomedecine, 9: 443-450. DOI: 10.5138/09750185.2106

Yéo YS. 2017. Evaluation de l'effets des biofongicides à base d'huile essentielles contre la Sclerotinose de la tomate (Solanum lypcopersicum L.) causée par Sclérotium rolfsii en Côte d'Ivoire. Mémoire de Master de l'Université Félix Houphouët-Boigny, Abidjan, Côte d'Ivoire, $47 \mathrm{p}$. 